\title{
PENERAPAN PENDEKATAN KOOPERATIF TIPE TGT PADA PEMBELAJARAN SAINS DALAM MENINGKATKAN HASIL BELAJAR ANAK DI KOTA MAKASSAR
}

\author{
Syamsul Alam Ramli \\ ${ }^{1}$ STKIP Muhammadiyah Palopo \\ Alamat Surat \\ E-mail: syamsulalamramli@email.com
}

\begin{abstract}
This study aims to implement a cooperative approach with the type of Team Games Tournament (TGT) model in SCIENCE learning in improving the learning outcomes of fifth grade students of Inpres Tidung Elementary School in Rappocini District, Makassar City. This research was carried out at SD Inpres Tidung, Rappocini Sub-District, Makassar City on September 5, 2011 until October 5, 2011. This study used a type of CAR (PTK) with the aim of knowing how to apply the Team Games Tournament (TGT) Cooperative Approach to SCIENCE learning in improving learning outcomes of fifth grade students of SD Inpres Tidung, Rappocini Subdistrict, Makassar City. The research target is children in class V in the academic year 2011/2012 odd semester as many as 34 children, totaling 11 boys and girls totaling 23 people. Data collection techniques through observation, documentation, and tests are analyzed through quantitative and qualitative techniques. The results show that there is an increase in children's learning outcomes in SCIENCE learning after getting learning through the Team Games Tournament (TGT) type. Learning activities in learning have increased in terms of cohesiveness in groups, asking questions during learning, children can solve problems encountered during learning, children can answer teacher's oral questions, children submit responses when learning takes place and are shown learning outcomes with test scores child.
\end{abstract}

Keywords: Cooperative Approach, Team Games Tournament, SCIENCE Learning.

\begin{abstract}
Abstrak
Penelitian ini bertujuan agar penerapan pendekatan kooperatif dengan model tipe Team Games Tournamen (TGT) pada pembelajaran SAINS dalam meningkatkan hasil belajar anak kelas V SD Inpres Tidung Kecamatan Rappocini Kota Makassar. Penelitian ini dilaksanakan di SD Inpres Tidung Kecamatan Rappocini Kota Makassar pada tanggal 05 September 2011 sampai dengan 05 Oktober 2011. Penelitian ini menggunakan jenis PTK (PTK) dengan tujuan untuk mengetahui bagaimanakah penerapan Pendekatan Kooperatif Tipe Team Games Tournamen (TGT) pada pembelajaran SAINS dalam meningkatkan hasil belajar anak kelas V SD Inpres Tidung Kecamatan Rappocini Kota Makassar. Sasaran penelitian adalah anak di kelas V pada tahun pelajaran 2011/2012 semester ganjil sebanyak 34 anak, yang berjumlah 11 orang anak laki-laki dan anak perempuan berjumlah 23 orang. Teknik pengumpulan data melalui observasi, dokumentasi, dan tes di analisis melalui teknik kuantitatif dan kualitatif. Hasil menunjukkan bahwa terjadi peningkatan hasil belajar anak pada pembelajaran SAINS setelah mendapatkan pembelajaran melalui tipe Team Games Tournamen (TGT). Aktivitas belajar kanadalam pembelajaran mengalami peningkatan dalam hal kekompakan secara berkelompok, mengajukan pertanyaan pada saat pembelajaran berlangsung, anak dapat menyelesaikan masalah yang dihadapi pada saat pembelajaran berlangsung, anak dapat menjawab pertanyaan lisan guru, anak mengajukan tanggapan saat pembelajaran berlangsung dan ditunjukkan hasil belajar dengan skor tes anak.
\end{abstract}

Kata Kunci,: Pendekatan Kooperatif, Team Games Tournamen, Pembelajaran SAINS. 


\section{PENDAHULUAN}

Pendidikan hakekatnya adalah suatu proses kehidupan yang memberi kemungkinan munculnya berbagai pilihan bagi seseorang dalam menata dan merancang kehidupan masa depannya yang lebih baik. Keadaan ini juga memunculkan persaingan yang cukup tajam dan sekaligus menjadi ajang seleksi alam yang kompetitif, sehingga diyakini hanya manusia dengan kualitas unggul sajalah yang akan mampu mengubah semuanya.

Disinilah peran penting seorang pendidik, khususnya dalam proses belajar mengajar di kelas. Tugas utamanya adalah menciptakan suasana pembelajaran yang kondusif bagi tumbuhnya partisipasi, komunikasi, interaksi belajar mengajar yang menyenangkan dan mencerdaskan. Sebagaimana hal ini tercantum dalam undang-undang SISDIKNAS no.20 pasal 1 tahun 2003 tentang sistem pendidikan nasional (2009: 2) menyatakan bahwa: "Pendidikan adalah usaha sadar dan terencana untuk mewujudkan suasana belajar dan proses pembelajaran agar peserta didik secara aktif mengembangkan potensi dirinya untuk memiliki kekuatan spiritual keagamaan, pengendalian diri, kepribadian, kecerdasan, akhlak mulia, serta keterampilan yang diperlukan dirinya, masyarakat, bangsa, dan negara."

Seiring dengan berjalanya perkembangan, yang terpenting adalah perubahan pada diri seseorang. Konteks pendidikan, paradigma belajar sepanjang hayat yang semakin mengemuka dan menjadi penting diyakini, tanpa belajar manusia akan tertinggal. Ketika dunia berkembang pesat, yang terpenting adalah mengikuti laju perubahan. Hal ini berarti kecepatan perubahan laju dunia menuntut kemampuan belajar yang lebih cepat, sehingga kompleksitasnya adalah bagaikan buku ibarat sebuah kompas menolong kita keluar dari kebodohan menuju padang pengetahuan yang indah, harum, dan bewarna-warni. Menurut Ahmad (Hasbullah, 2009:3) bahwa pendidikan adalah bimbingan atau pimpinan secara sadar oleh si pendidik terhadap perkembangan jasmani dan rohani si terdidik menuju terbentuknya kepribadian yang utama.

Adanya perkembangan zaman inilah, maka persoalan dapat dipecahkan melalui informasi baru yang diperoleh. Tetapi harus dipahami pula bahwa aktivitas belajar setiap individu, tidak selamanya dapat berlangsung sebagaimana mestinya. Kadang-kadang aktivitas itu dapat berjalan dengan lancar, dan kadang-kadang pula tidak berjalan dengan lancar. Ketika belajar, seseorang terkadang juga mengalami situasi yang disebut "jenuh belajar". Kejenuhan belajar dapat melanda siapapun yang kehilangan semangat dan motivasi belajar khususnya siswa kelas V SD Inpres Tidung Kecamatan Rappocini Kota Makassar. 
Berdasarkan data yang diperoleh di sekolah tersebut bahwa terdapat sejumlah siswa yang aktif pada kelas V sebanyak 34 orang, yang terdiri dari 11 orang laki-laki dan 23 orang perempuan yang terdaftar pada semester ganjil tahun ajaran 2011-2012 dan diperoleh keterangan bahwa hasil belajar SAINS masih tergolong rendah.

Salah satu kendala utama adalah kurangnya antusias sebagian siswa untuk belajar dikarenakan (1) guru kurang melibatkan siswa dalam belajar kelompok, hanya menggunakan pembelajaran klasikal sehingga pengetahuan siswa hanya semata-mata apa yang disampaikan oleh guru dan siswa tidak mengemukakan secara langsung ide yang mereka peroleh sehingga mengakibatkan kurangnya pemahaman siswa dalam pembelajaran SAINS. (2) siswa sering beralasan malas mendengarkan penjelasan yang diberikan guru atau sering beralasan keluar masuk meminta izin dengan alasan buang air kecil, meludah, atau berpura-pura buang sampah tanpa mengikuti jam pelajaran. Ini mengakibatkan kurangnya perhatian dari guru kelasnya (3) guru dalam mengajar lebih banyak mendominasi proses pembelajaran dengan cara paradigma lama. (4) guru terlalu menoton pada PBM. (5) kurangnya kesadaran pada diri guru, yang harus diperbaiki dengan prakarsa perbaikan dari guru itu sendiri, bukan oleh orang dari luar.

Rendahnya hasil belajar terhadap siswa tersebut akan mengakibatkan pembelajaran kurang optimal. Hal ini dikarenakan adanya faktor penghambat, dimana pembelajaran yang dilakukan oleh guru tersebut pada awalnya menggunakan model pembelajaran, akan tetapi pada proses belajar mengajar guru masih tetap cenderung menggunakan cara paradigma lama. Paradikma lama dalam proses pembelajaran adalah guru memberi pengetahuan pada siswa secara pasif. Dalam konteks pendidikan, paradigma lama ini juga berarti jika seorang mempunyai pengetahuan dan keahlian dalam suatu bidang tertentu, ia pasti akan dapat mengajar, ia tidak perlu tahu proses belajar mengajar yang tepat, ia hanya perlu menuangkan apa yang diketahuinya kedalam botol kosong yang siap menerimanya. Namun ia masih menganggap paradigma lama itu sebagai satu-satunya cara mengajar yang baik dengan strategi ceramah, dan mengharapkan siswa datang, duduk, diam, dengar, catat, dan hafal.

Melalui keadaan pembelajaran seperti itu, mengakibatkan siswa tidak serius mengikuti pelajaran, merasa bosan dan jenuh bahkan pada saat pemberian tugas kelompok, hanya saja 1-7 siswa dapat mengerti dibandingkan dengan yang lain khususnya mata pelajaran Ilmu Pengetahuan Alam (SAINS) yang dianggapnya tidak penting. 
Akibatnya sebahagian siswa malas dan dianggapnya sebagai pelajaran yang, membosankan, dan kurang diminati. Jika hal ini tidak diatasi, maka dalam proses pembelajaran SAINS akan dpastikan mengalami pembelajaran yang kurang optimal dan akan menyebabkan rendahnya hasil belajar siswa yang akhirnya akan mengakibatkan rendahnya mutu pendidikan.

Berdasarkan hasil observasi, peneliti menduga bahwa model pembelajaran yang digunakan selama ini belum efektif, ini menyebabkan karena rendahnya hasil belajar SAINS khususnya siswa kelas V SD Inpres Tidung Kecamatan Rapocini Kota Makassar. Dengan dasar inilah diharapkan adanya pembelajaran yang dapat memperbaiki model pembelajaran yang digunakan dalam proses belajar mengajar sehingga pembelajaran yang digunakan guru tersebut dapat optimal dikarenakan hal itu sangat penting dilakukan guna mencapai tujuan pembalajaran.

Untuk memperbaiki proses pembelajaran yang efektif maka penulis tertarik untuk melakukan penelitian. Berdasarkan Atas dugaan, peneliti menawarkan suatu tindakan alternatif dengan pertimbangan untuk mengatasi masalah yang ada berupa penerapan model pembelajaran lain yang lebih mengutamakan keaktifan siswa dengan memberi kesempatan untuk mengembangkan potensinya secara maksimal. Pembelajaran yang dimaksud adalah Pendekatan Kooperatif Tipe Team Games Tournamen.

Hal ini berarti bahwa TGT sangat memegang peranan penting dalam upaya meningkatkan hasil belajar siswa khususnya dalam pembelajaran SAINS. Model ini pernah dikembangkan secara asli oleh David De Vries dan Keath Edward, 1995 (Trianto, 2009:83) dan hasilnya memuaskan. Pembelajaran ini dinilai lebih memudahkan siswa berinteraksi dengan temanteman dalam kelas yang dapat membuat pembelajaran jadi menyenangkan sehingga pelajar dapat menguasai pembelajaran melalui model TGT dibandingkan dengan cara paradikma lama yang selama ini diterapkan oleh guru tersebut.

Suasana pembelajaran yang menyenangkan memudahkan siswa menerima informasi dan menyimpannya dalam jangka waktu yang lama karena terjadi peningkatan gelombang otak (Rustan \& Bahru, 2018). Namun, dengan adanya paradigma lama mengenai model pembelajaran maka pembelajaran dapat dikembangkan melalui model pembelajaran kooperatif tipe TGT. Pembelajaran kooperatif didefinisikan sebagai suatu sistem pembelajaran di mana siswa diberi kesempatan untuk menyelesaikan masalah, menyelesaikan tugas untuk mencapai tujuan bersama, dalam suatu kelompok heterogen yang berjumlah 5 kelompok.

PiJIES: Pedagogik Journal of Islamic Elementary School 
Selain itu juga bahwa ciri khas pembelajaran kooperatif adalah siswa ditempatkan pada kelompok-kelompok kerja dan tinggal bersama sebagai satu kelompok untuk beberapa minggu atau beberapa bulan. Siswa dilatih keterampilan-keterampilan spesifik untuk membantu mereka bekerja sama yang baik.

SAINS merupakan singkatan dari ilmu pengetahuan alam yang berasal dari kata natural science yang artinya ilmu pengetahuan. Dimana, natural artinya alamiah dan berhubungan dengan alam. Sedangkan science artinya ilmu pengetahuan. Jadi SAINS secara harfiah adalah ilmu pengetahuan tentang alam atau yang mempelajari peristiwa-peristiwa yang terjadi di alam. Menurut Harlen (Patta dan Ratna, 2010) mengemukakan tiga karakteristik utama SAINS yakni: Pertama, memandang bahwa setiap orang memunyai kewenangan untuk menguji validasi prinsip dan teori ilmiah. Meskipun kelihatannya logis dan dapat dijelaskan secara hipotesis, teori, dan prinsip hanya berguna jika sesuai dengan kenyataan yang ada. Kedua, memberi pengertian adanya hubungan antara fakta-fakta yang diobservasi yang memungkinan penyusunan prediksi sebelum sampai pada kesimpulan. Teori yang disusun harus didukung oleh fakta-fakta dan data yang teruji kebenarannya. Ketiga, memberi makna bahwa teori SAINS bukanlah kebenaran yang akhir tetapi akan berubah atas dasar suatu perangkat pendukung teori tersebut. Atas dasar pola pikir tersebut, SAINS secara garis besar memiliki tiga komponen, yaitu: (1) proses ilmiah, (2) produk ilmiah, (3) sikap ilmiah. Pendidikan SAINS merupakan cara mencari tahu tentang alam secara sistematik untuk menguasai pengetahuan, fakta-fakta, konsep-konsep, proses penemuan, dan memiliki sikap ilmiah. Pendidikan SAINS menekankan pada pemberian pengalaman langsung dan kegiatan praktis untui mengembangkan kompetensi agar peserta didik mampu menjelajahi dan memahami alam sekitar secara ilmiah. Pendidikan ilmu pengetahuan alam diarahkan untuk mencari tahu dan berbuat sehingga dapat membantu peserta didik untuk memperoleh pemahaman yang lebih mendalam tentang alam sekitar.

Salah satu yang dilakukan siswa dalam menempuh studi adalah belajar. Tetapi dalam proses belajar, siswa seringkali mengalami yang namanya kesulitan. Namun, kita tidak akan tahu sesuatu hal jika kita tidak ingin mencarinya. Kesulitan yang menghadang akan mudah diatasi jika siswa memiliki efikasi diri yang tinggi atau keyakinan akan kemampuan yang dimilikinya (Thaha \& Rustan, 2017). Siswa dengan efikasi diri akan lebih mampu mengatasi tuntutan-tuntutan yang dihadapi dibandingkan siswa dengan efikasi rendah. 
Pada hakekatnya belajar adalah suatu proses yang ditandai adanya perubahan pada diri siswa. Perubahan tersebut sebagai hasil dari proses belajar yang dapat dilihat dari berbagai bentuk seperti perubahan pada segi pendidikan, pemahaman, sikap, tingkah laku, serta aspek-aspek lainnya yang ada pada diri siswa yang belajar. Belajar bukanlah sekedar mengumpulkan pengetahuan akan tetapi belajar adalah proses mental yang terjadi dalam diri seseorang, sehingga menyebabakan munculnya perubahan perilaku. Dengan kata lain bahwa belajar adalah suatu proses jadi tidak tahu menjadi tahu. Menurut Burton (Usman, 1994) mendefenisikan belajar diartikan sebagai perubahan tingka laku pada diri individu berkat adanya interaksi antara individu dan individu dengan lingkungannya, dengan adanya perubahan pada tingkah laku pada diri seseorang maka secara keseluruhan dapat menimbulkan kelakuan baru, merubah sikap seseorang menjadi lebih baik dari tingka laku sebelumnya.

Sasaran dari kegiatan belajar mengajar adalah hasil belajar. Apabila proses belajar mengajar berjalan dengan baik, maka hasil belajar juga baik. Artinya hasil belajar harus bisa dimanfaatkan sebaik-baiknya oleh pengajar dalam menyelesaikan suatu masalah dan sebagai pertimbangan dalam langkah selanjutnya. Tujuan tercapai jika siswa memperoleh hasil belajar mengajar tersebut. Oleh sebab itu, hasil belajar ini dapat diukur dengan menggunakan tes hasil belajar. Inti belajar adalah adanya perubahan pengetahuan, pemahaman, keterampilan, dan sikap yang diperoleh melalui pengalaman dan refleksi pengalaman (Patta dan Ratna, 2010).

\section{METODE}

Pendekatan yang digunakan dalam penelitian ini adalah menggunakan pendekatan kualitatif deskriptif. Jenis penelitian yaitu Penelitian Tindakan Kelas (PTK). Fokus pada Penerapan Pendekatan Kooperatif Tipe TGT. Penelitian dilaksanakan di SD Inpres Tidung Kecamatan Rappocini Kota Makassar yang beralamat di jalan Bonto Dg. Ngirate No. 10 A. Sasaran penelitian adalah siswa kelas V SD Inpres Tidung Kecamatan Rappocini Kota Makassar yang berjumlah 34 orang terdiri dari 11 orang laki-laki dan 23 orang perempuan yang aktif dan akan diteliti dengan sasaran utama meningkatkan hasil belajar siswa kelas V di SD Inpres Tidung Kecamatan Rappocini Kota Makassar. Pelaksanaan penelitian tindakan kelas ini dirancang dalam dua siklus kegiatan. Tiap siklus terdiri dari beberapa tahap kegiatan sesuai hakikat penelitian. Kegiatan pada siklus II merupakan pengulangan dan perbaikan dari siklus I.

PiJIES: Pedagogik Journal of Islamic Elementary School 
Adapun metode pengumpulan data yang dilakukan untuk menunjang penulisan ini yaitu Observasi, Tes , dan Dokumentasi. Teknik Analisis Data, Data pelaksanaan Penelitian Tindakan Kelas (PTK) dianalisis dengan menggunakan data kuantitatif dan data kualitatif. Berikut teknik kategorisasi standar dari sumber Evaluasi Pengajaran (Rahmat dan Suherdi, Depdikbud) yaitu: skor 85-100 kategori Sangat Tinggi, 65-84 kategori Tinggi, 55-64 kategori Sedang, 35-54 kategori Rendah, 0-34 kategori Sangat Rendah.

Teknik analisis data kualitatif dapat dilakukan melalui dengan tiga tahapan, yaitu: Reduksi data, Penyajian data, dan Mengambil kesimpulan. Indikator keberhasilan penelitian tindakan kelas ini adalah apabila terjadi peningkatan hasil belajar siswa kelas $V$ terhadap pembelajaran SAINS setelah diterapkannya model pembelajaran TGT terdapat 85\% siswa yang memperoleh skor minimal 60 ke atas dianggap tuntas secara klasikal berdasarkan pada Kriteria Ketuntasan Minimal (KKM) yaitu di atas rata-rata maka kelas tersebut dianggap tuntas secara klasikal.

\section{HASIL PENELITIAN DAN PEMBAHASAN}

\section{Deskripsi Hasil Penelitian}

Berdasarkan hasil penelitian bahwa terdapat adanya peningkatan hasil belajar siswa dikarenakan adanya perubahan belajar, pemahaman, keterampilan, dan sikap yang diperoleh melalui pengalaman dan refleksi aktivitas belajar siswa dan mengajar guru. Melalui penerapan Pendekatan kooperaif tipe TGT diperoleh adanya peningkatan terhadap belajar siswa setelah dilakukannya pembelajaran SAINS dengan pokok bahasan alat pencernaan manusia. Penelitian ini dilaksanakan di SD Inpres Tidung Kecamatan Rappocini Kota Makassar pada tanggal 05 September sampai dengan 05 Oktober 2011. Subjek penelitian ini adalah siswa kelas V pada semester ganjil pada tahun pelajaran 2011-2012 sebanyak 34 orang.

Penelitian ini bertujuan untuk meningkatkan hasil belajar siswa melalui penerapan Pendekatan kooperaif tipe TGT pada pembelajaran SAINS. Penelitian ini terdiri dari 2 siklus yang terdiri dari empat tahap yakni tahap perencanaan, tindakan, observasi dan refleksi. Data yang diperoleh dari hasil tes awal yang mencapai nilai rata-rata $34 \%$. Bila dibandingkan dengan Kriteria Ketuntasan Minimal (KKM) berdasarkan Kurikulum Tingkat Satuan Pendidikan yakni senilai $60 \%$ maka, dapat dikategorikan bahwa nilai tersebut berada dibawah standar ketuntasan yang diharapkan.

Pelaksanaan pembelajaran pada siklus I merupakan kegiatan proses pembelajaran yang dilakukan untuk mengetahui tindakan hasil belajar siswa setelah diterapkannya pembelajaran kooperatif tipe TGT pada pembelajaran 
SAINS dengan pokok bahasan alat pencernaan manusia. Data yang diperoleh dari kegiatan proses pembelajaran ini merupakan hasil tes belajar dan perilaku siswa selama proses pembelajaran. Pada pelaksanaan pembelajaran ini dilakukan selama 2 kali pertemuan pada tanggal 09 s/d 13 September 2011. Kegiatan ini terdiri dari empat tahap yaitu perencanaan, pelaksanaan tindakan, observasi, dan refleksi.

Hasil analisis deskriptif terhadap skor perolehan hasil belajar siswa setelah diterapkannya tipe TGT pada pembelajaran SAINS Menunjukkan data statistik skor hasil belajar siswa berdasarkan hasil tes pada siklus I terdapat bahwa subjek penelitian berjumlah 34 siswa dengan skor ideal 100, Skor yang dicapai responden dengan skor tertinggi 80, skor terendah 20 dan skor ratarata 47 dengan rentang skor 60 , titik tengah dari data terkecil ke data yang besar atau median (Me) adalah 50 sedangkan data yang sering muncul (Mo) adalag 50. Berdasarkan pengamatan selama proses pembelajaran bahwa terdapat siswa yang aktif mengikuti pembelajaran justru tidak tuntas bila diberi tes formatif, sedangkan siswa yang pada dasarnya kurang aktif, justru hasil tes belajarnya tuntas dibandingkan siswa yang lebih aktif pada proses pembelajaran. Hal ini menunjukkan bahwa tingkat kemampuan hasil belajar siswa masih tergolong rendah.menunjukkan bahwa dari 34 siswa kelas V SD Inpres Tidung Kec. Rappocini Kota Makassar persentase skor hasil belajar siswa setelah dilaksanakan penerapan TGT pada pembelajaran SAINS, ada 8 siswa (24\%) yang berada pada kategori sangat rendah, ada 15 siswa (44\% ) berada pada kategori rendah, ada 9 siswa (26\%) berada pada kategori sedang, ada 2 siswa (6\%) berada pada kategori tinggi dan tidak ada siswa $(0 \%)$ siswa berada pada kategori sangat tinggi. Hasil menunjukkan bahwa dari 34 siswa terdapat 11 siswa (32\%) yang tuntas belajar dan 23 siswa (68\%) yang belum tuntas belajar. Hasil belajar siswa pada siklus I menunjukkan bahwa hasil pembelajaran SAINS pada siklus I hanya 11 siswa dari 34 siswa yang mendapat 60 ke atas dikategorikan tuntas, dan 23 siswa dari 34 siswa yang mendapat 60 ke bawah dikategorikan tidak tuntas.

Hasil observasi atau pengamatan kegiatan mengajar guru pada siklus I menunjukkan bahwa pada pertemuan 1 dengan jumlah 16 persentase 76,19\% dengan kategori tinggi. Sedangkan, pada pertemuan 2 dengan jumlah 17 persentase 70,83\% dengan kategori tinggi. Gambaran aktivitas belajar siswa pada siklus I merupakan pengamatan yang dilakukan oleh peneliti terhadap aktivitas belajar siswa. Hasil observasi yang terangkum dalam lembar aktivitas siswa menggambarkan tentang aktivitas belajar siswa. Untuk mengetahui perubahan sikap siswa dalam proses belajar dan pembelajaran dapat kita lihat pada hasil observasi yang dilakukan pada setiap pertemuan.

PiJIES: Pedagogik Journal of Islamic Elementary School 
Pada pertemuan kedua, siswa sudah siap untuk mengikuti turnamen. Pada pelaksanaan turnamen mereka bugitu antusias untuk mengikuti pembelajaran yang dinanti-nantikan oleh siswa tersebut. Kegiatan pembelajaran berjalan cukup lancar dan perhatian siswa terhadap materi pelajaran lebih baik. Hal ini ditunjukkan oleh banyaknya siswa yang aktif saat kegiatan pembelajaran berlangsung seperti aktif bertanya, menjawab pertanyaan, meminta bimbingan guru dan antusias dalam turnamen yang diberikan.

Pada Siklus II, Pelaksanaan pembelajaran ini berlangsung selama 2 kali pertemuan (tanggal 16 s/d 10 September 2011). Kegiatan ini terdiri dari empat tahap yaitu tahap perencanaan, tahap pelaksanaan tindakan, tahap observasi dan tahap refleksi.

Hasil analisis deskriptif Menunjukkan data statistik skor hasil belajar siswa berdasarkan hasil tes pada siklus I terdapat bahwa subjek penelitian berjumlah 34 siswa dengan skor ideal 100, Skor yang dicapai responden dengan skor tertinggi 100, skor terendah 40 dan skor rata-rata 80,29 dengan rentang skor 60 , titik tengah dari data terkecil ke data yang besar atau median (Me) adalah 80 sedangkan data yang sering muncul (Mo) adalah 80. Hasil menunjukkan bahwa dari 34 siswa kelas V SD Inpres Tidung Kecamatan Rappocini Kota Makassar persentase skor hasil belajar siswa setelah dilaksanakan penerapan TGT pada pembelajaran SAINS, tidak ada siswa (0\%) yang berada pada kategori sangat rendah, 3 siswa (9\%) berada pada kategori rendah, 3 siswa (9\%) berada pada kategori sedang, 14 siswa (41\%) berada pada kategori tinggi, dan 14 siswa (41\%) berada pada kategori sangat tinggi. Berdasarkan hasil analisis diperoleh skor rata-rata hasil belajar siswa pada siklus II sebesar 80,29. Data menunjukkan bahwa dari 3 siswa terdapat $9 \%$ yang belum tuntas belajar dan 31 siswa terdapat $91 \%$ yang tuntas belajar. Ini berarti ketuntasan belajar pada siklus II tercapai secara klasikal karena jumlah siswa yang tuntas mencapai lebih dari $91 \%$. Dengan demikian hasil pembelajaran SAINS pada siklus II hanya 31 siswa dari 34 siswa yang mendapat 60 ke atas dikategorikan tuntas, dan 3 siswa dari 34 siswa yang mendapat 60 ke bawah dikategorikan tidak tuntas.

Hasil tes pada siklus I menunjukkan bahwa subjek penelitian berjumlah 34 siswa dengan skor ideal 100, Skor yang dicapai responden dengan skor tertinggi 80, skor terendah 20 dan skor rata-rata 47 dengan rentang skor 60, titik tengah dari data terkecil ke data yang besar atau median (Me) adalah 50 sedangkan data yang sering muncul (Mo) adalah 50. Pada siklus II menunjukkan bahwa subjek penelitian berjumlah 34 siswa dengan skor ideal 100 , Skor yang dicapai responden dengan skor tertinggi 100, skor terendah 40 dan skor rata-rata 80,29 dengan rentang skor 60, titik tengah dari data terkecil 


\section{2 | Syamsul Alam Ramli}

ke data yang besar atau median (Me) adalah 80 sedangkan data yang sering muncul (Mo) adalag 80. Hasil yang menunjukkan peningkatan hasil belajar setelah dilaksanakan tes pada siklus I dan II. Pada siklus I bahwa terdapat 8 siswa (24\%) berada pada kategori sangat rendah. 15 siswa (44\%) berada pada kategori rendah, 9 siswa (26\%) berada dalam tingkat penguasaan sedang, 2 siswa $(6 \%)$ berada pada kategori tinggi, tidak ada siswa (0\%) yang berada pada tingkat penguasaan sangat tinggi. Sedangkan, pada siklus II bahwa tidak ada siswa (0\%) berada pada kategori sangat rendah. 3 siswa (9\%) berada pada kategori rendah, 3 siswa (9\%) berada dalam tingkat penguasaan sedang, 14 siswa (41\%) berada pada kategori tinggi, 14 siswa (41\%) yang berada pada tingkat penguasaan sangat tinggi.

Hasil pembelajaran SAINS pada siklus I hanya 11 siswa dari 34 siswa yang mendapat 60 ke atas dikategorikan tuntas, dan 23 siswa dari 34 siswa yang mendapat 60 ke bawah dikategorikan tidak tuntas. Sedangkan, pada siklus II hanya 31 siswa dari 34 siswa yang mendapat 60 ke atas dikategorikan tuntas, dan 3 siswa dari 34 siswa yang mendapat 60 ke bawah dikategorikan tidak tuntas. Observasi, Langkah-langkah pembelajaran pada siklus II relatif sama dengan pelaksanaan tindakan siklus I. pelaksanaan tindakan mengacu pada Rencana Pelaksanaan Pembelajaran, pelaksanaan tindakan pada siklus II dilaksanakan selama dua kali pertemuan dengan materi pokok pembelajaran "Sistem Alat Pencernaan pada Manusia" proses pembelajaran dilaksanakan dengan metode ceramah singkat, tanya jawab, demonstrasi dan penugasan.

Untuk mengetahui perubahan sikap guru SD Inpres Tidung Kecamatan Rappocini Kota Makassar dapat dilihat dari hasil observasi guru dapat diketahui bahwa data aktivitas mengajar guru kelas $\mathrm{V}$ menunjukkan bahwa pada pertemuan 1 dengan jumlah 20 persentase 95,23\% dengan kategori sangat tinggi sedangkan bahwa pada pertemuan 2 dengan jumlah 24 persentase $100 \%$ dengan kategori sangat tinggi. Ini berarti mengalami peningkatan jika dibandingkan dengan tes yang dilaksanakan pada akhir Siklus I.

\section{Pembahasan Hasil Penelitian}

Pembahasan Hasil Penelitian pada Hasil Belajar Siswa dengan Penerapan TGT, Berdasarkan analisis deskriptif hasil belajar SAINS siswa kelas V SD Inpres Tidung Kecamatan Rappocini Kota Makassar, diperoleh bahwa rata-rata skor tes hasil belajar siswa pada Siklus I adalah 47,05 sedangkan rata-rata skor hasil belajar siswa pada Siklus 2 adalah 80,29 dari skor ideal 100 yang mungkin dicapai. Hal ini menunjukkan bahwa secara kuantitatif terjadi peningkatan rata-rata skor tes hasil belajar SAINS siswa 
kelas V SD Inpres Tidung Kecamatan Rappocini Kota Makassar dan daya serap terhadap materi setelah penerapan TGT pada pembelajaran SAINS.

Pada Siklus II tampak bahwa hampir semua siswa mengalami peningkatan skor tes hasil belajar SAINS. Hal ini disebabkan karena pada siklus II siswa telah mampu menyelesaikan soal sesuai prosedur yang diharapkan sehingga pada umumnya siswa tersebut dapat memperoleh skor pada setiap butir soal. Setelah dilakukan pembelajaran SAINS dengan penerapan tipe TGT siswa mampu menginterpretasikan maksud soal tes. Terjadinya peningkatan skor tes hasil belajar SAINS siswa kelas V SD Inpres Tidung Kecamatan Rappocini Kota Makassar berarti pula bahwa pada siklus II terjadi peningkatan daya serap siswa terhadap materi pelajaran. Peningkatan daya serap tersebut diikuti dengan peningkatan ketuntasan belajar siswa. Dari 34 siswa sebanyak 11 siswa (32\%) yang mencapai ketuntasan belajar pada Siklus I meningkat menjadi 31 siswa (91\%) yang mencapai ketuntasan belajar pada Siklus II. Hal ini menunjukkan bahwa pada Siklus II ketuntasan belajar secara klasikal tercapai.

Perubahan Sikap Siswa, Berdasarkan analisis deskriptif aktivitas belajar siswa diperoleh bahwa terjadi peningkatan aktivitas belajar siswa kelas V SD Inpres Tidung Kecamatan Rappocini Kota Makassar. Jika dibandingkan hasil observasi siklus I dan siklus II, persentase perhatian dan keseriusan siswa dalam proses belajar dan pembelajaran meningkat. Persentase rata-rata jumlah siswa yang dapat menyelesaikan masalah berkaitan dengan materi pembelajaran dengan menggunakan konteks yang nyata, model-model yang berhubungah dengan kehidupan sehari-hari siswa meningkat. Persentase rata-rata jumlah siswa yang memberikan, mengajukan pertanyaan, dan tanggapan terhadap pertanyaan guru meningkat. Persentase rata-rata jumlah setiap kelompoknya meningkat. Persentase rata-rata jumlah siswa yang mampu menyelesaikan tugasnya sendiri meningkat. Persentase turnamen dengan kategori tinggi, sedang, sedang, rendah mengalami peningkatan.

Terjadinya peningkatan persentase aktivitas belajar siswa, kehadiran siswa mengikuti proses pembelajaran dan jumlah siswa yang mengajukan diri dan tampil menyelesaikan tugas kelompok dan menunjukkan bahwa siswa memiliki perhatian yang cukup besar dalam belajar SAINS, khususnya dalam penelitian ini. Peningkatan jumlah siswa yang menanggapi pertanyaan guru atau teman dan yang mengajukan pertanyaan menunjukkan antusias siswa untuk mengikuti proses pembelajaran SAINS dengan penerapan TGT. Peningkatan jumlah siswa yang mengajukan pertanyaan dapat diinterpretasikan bahwa sebagian besar siswa merasa sulit mengerjakan LKS dan soal latihan. Namun hal ini juga menunjukkan bahwa keinginan mereka 


\section{4 | Syamsul Alam Ramli}

dalam menyelesaikan tugas berani mengajukan pertanyaan dan memecahkan persoalan mereka yang patut dihargai dan direspon secara positif.

Peneliti menyadari bahwa untuk menumbuhkan minat belajar siswa pada pembelajaran SAINS, perlu dirancang pembelajaran yang mengaitkan materi yang dipelajari dengan situasi kehidupan nyata siswa, yang terpenting juga adalah antusias siswa untuk belajar, keberanian mengungkapkan gagasan, ide dan pemikiran serta menumbuhkan motivasi untuk belajar SAINS. Adanya peningkatan aktivitas belajar siswa pada siklus II tersebut menunjukkan bahwa banyak kemajuan yang dicapai oleh siswa setelah dilaksanakan penerapan TGT. Uraian tersebut di atas menunjukkan bahwa dengan penerapan TGT dapat mengubah sikap siswa pada pembelajaran SAINS dan dapat meningkatkan keseriusan siswa untuk belajar.

Berdasarkan hasil yang diperoleh dalam penelitian ini menunjukkan bahwa terjadi peningkatan hasil belajar siswa pada pembelajaran SAINS setelah mendapatkan pembelajaran kooperatif tipe Team Games Tournamen (TGT). Aktivitas belajar siswa dalam pembelajaran mengalami peningkatan dalam hal kekompakan secara berkelompok, mengajukan pertanyaan pada saat pembelajaran berlangsung, siswa dapat menyelesaikan masalah yang dihadapi pada saat pembelajaran berlangsung, siswa dapat menjawab pertanyaan lisan guru, siswa mengajukan tanggapan saat pembelajaran berlangsung dan hasil belajar siswa yang ditunjukkan dengan skor tes siswa. Berdasarkan hasil yang diperoleh dalam penelitian ini, diajukan beberapa saran sebagai berikut: Melalui Penerapan Pendekatan Kooperatif Tipe Team Games Tournamen (TGT) dapat dijadikan sebagai salah satu pendekatan suatu alternatif dalam melaksanakan pembelajaran SAINS di sekolah tersebut, sehingga dalam proses pembelajaran siswa dapat mengalami peningkatan belajar yang lebih bermakna. Dalam proses pembelajaran diharapkan perlu menguasai beberapa pendekatan dan metode pembelajaran sehingga pelaksanaan pembelajaran dapat lebih bervariasi sehingga siswa tidak merasa bosan dalam belajar dan akan lebih mudah memahami materi. Sebagai tindak lanjut penerapan pada saat proses pembelajaran, diharapkan guru lebih kreatif dalam menyajikan permasalahan agar siswa dapat lebih termotivasi dan lebih terlatih dalam berfikir untuk menemukan penyelesaian terhadap masalah. Diharapkan kepada peneliti lain dalam bidang kependidikan khususnya pada pembelajaran SAINS supaya dapat meneliti lebih lanjut tentang metode yang efektif dan efisien untuk mengatasi kesulitan siswa dalam mempelajari pembelajaran SAINS.

PiJIES: Pedagogik Journal of Islamic Elementary School 


\section{PENUTUP}

Berdasarkan hasil yang diperoleh dalam penelitian ini menunjukkan bahwa terjadi peningkatan hasil belajar siswa pada pembelajaran SAINS setelah mendapatkan pembelajaran kooperatif tipe Team Games Tournamen (TGT). Aktivitas belajar siswa dalam pembelajaran mengalami peningkatan dalam hal kekompakan secara berkelompok, mengajukan pertanyaan pada saat pembelajaran berlangsung, siswa dapat menyelesaikan masalah yang dihadapi pada saat pembelajaran berlangsung, siswa dapat menjawab pertanyaan lisan guru, siswa mengajukan tanggapan saat pembelajaran berlangsung dan hasil belajar siswa yang ditunjukkan dengan skor tes siswa.

\section{DAFTAR PUSTAKA}

Arikunto, Suharsimi, Suhardjono, dan Supardi. 2008. Penelitian Tindakan Kelas. Jakarta: Bumi Aksara.

Bundu, Patta. 2010. Konsep Dasar SAINS I. Makassar: Universitas Negeri Makassar.

Haling. Abdul. dkk. 2007. Belajar dan Pembelajaran. Makassar: Universitas Negeri Makassar.

Hasbulah. 2009. Dasar-dasar Ilmu Pendidikan. Jakarta : PT Raja Grafindo Persada.

Ibrahim,N. 1999. Pemanfaatan Tutorial Audio Interaktif untuk Perataan Hasil Belajar, Jurnal Pendidikan Dan Kebudayaan.

Iskandar, 2009. Penelitian Tindakan Kelas. CSAINSyung-Ciputat, Bandung: Gaung Persada (GP) Press.

Mulyasa, 2008. Menjadi Guru Profesional menciptakan Pemebelajaran Kreatif dan Menyenangkan. Bandung, Remaja Rosdakarya.

Rahmat, Cece dan Suherdi, Didi. 1999. Evaluasi Pengajaran. Depdikbud.

Rusman. 2010. Model-model Pembelajaran (Mengembangkan Propesionalisme Guru). Jakarta: Rajawali Pers.

Rustan, E., \& Bahru, M. S. (2018). Penguatan Self Confidence dalam Pembelajaran Matematika melalui Metode Suggestopedia. Al-

Khwarizmi: Jurnal Pendidikan Matematika Dan Ilmu Pengetahuan Alam, 6(1), 1-14.

Saptono, 2003. Cooperative learning. Jakarta, Sinar Baru.

Slavin, Robert E. 2009. Cooperaive Laearning (Teori, Riset dan Praktik). Cetakan ke-III. Bandung: Nusa Media.

Sukarmin. 2002. Pembelajaran Coperatif. Solo. Tiga Serangkai

Taniredja, Tukiran dkk. 2010. Penelitian Tindakan Kelas. Bandung: Alfabeta.

Thaha, H., \& Rustan, E. (2017). Orientasi Religiusitas dan Efikasi Diri dalam Hubungannya dengan Kebermaknaan Pendidikan Agama Islam pada Mahasiswa IAIN Palopo. Studi Agama Dan Masyarakat, 13(2), 163-179. https://doi.org/10.23971/jsam.v13i2.551

Tiro. A. 2002. Dasar-Dasar Statistik. Ujung Pandang: UNM 
Trianto, 2009. Mendesain Model Pembelajaran Inovatif-Progresif. Kencana Prenada Media Group: Jakarta.

Undang-Undang SISDIKNAS No.20 pasal 1. 2003. Sistem Pendidikan Nasional. Bandung: Citra Umbara.

Usman. Moh Uzer. 1994. Menjadi Guru Profesional. Bandung: PT Remaja Rosdakarya 